\title{
The rise and fall of cash for care in Norway: changes in the use of child-care policies
}

\section{Brita Bungum}

Programme for Teacher Education

The Norwegian University of Science and Technology (NTNU)

Email: Brita.Bungum@plu.ntnu.no

\section{Elin Kvande}

Department of Sociology and Political Science

The Norwegian University of Science and Technology (NTNU)

\section{Email: Elin.Kvande@svt.ntnu.no}

\begin{abstract}
The cash-for-care scheme was introduced in 1998 in Norway. During the first period after its introduction, the percentage of users was high at 91 per cent. Since 2005, however, the use has decreased substantially year by year. Thus, the use of cash for care has changed over the 15 years it has existed. In this article we take these changes as our point of departure and analyse more closely what we might call 'the rise and fall of the cash-for-care scheme' in Norway. Over the last 15 to 20 years, Norway has become a multicultural society and we need to include ethnicity when conducting research in the field of family policy. The focus is therefore on the intersection of gender, class, and ethnicity in parents' use of cash for care over this period. Our analysis is based on different sources of data. We have used data from the evaluative programme undertaken by the Norwegian Research Council, including two surveys conducted before and after the reform (Gulbrandsen \& Hellevik, 1998; Hellevik, 2000), and a qualitative case study focusing on fathers and mothers working in three different workplaces (Bungum et al. 2001). We have also used
\end{abstract}

NJSR - Nordic Journal of Social Research

Vol. 4, 2013 
three other statistical studies which were carried out at two different points in time (Pettersen, 2003; Hirch, 2010; Bakken \& Myklebo, 2010). Our findings indicate that cash for care is a scheme that mainly encourages mothers who have low income and a low educational level and who are to a large degree from immigrant backgrounds to remain outside the labour market. By distinguishing between three phases, we have aimed to illustrate how the intersection of gender, class, and ethnicity enters in different ways into both the discourse and the practices connected to the cash-for-care scheme since it was introduced in 1998.

Keywords: welfare state, cash for care, family policy, class, gender, ethnicity

\section{Introduction}

Policies facilitating the reconciliation of work and family in Norway, as in many other Nordic countries, have been influenced by the idea of gender equality between parents. The focus has therefore been on promoting both mothers' and fathers' participation in work and childcare. The parental-leave scheme and high-standard day-care services encourage the model of the dual-earner and the dual-carer family. Although this has been the main principle, another principle that supports a traditional family model in the policy measures in this field has been observed. This principle has been labelled the 'double track' and has been referred to as a dualism in Norwegian family policy (Ellingsæter \& Leira, 2006). During the 1990s two important family policy reforms were introduced in Norway. These two reforms illustrate the dualism in the welfare-state provisions for work-family regulation. In 1993 Norway extended the parental-leave scheme to one year of paid leave and introduced the father's quota. These were policy measures which fit the idea of the dual-earner and the dualcarer model. In 1998, however, the cash-for-care scheme was introduced. Before its introduction it was the subject of a heated and polarized debate in Norway.

Concerns about the 'time squeeze' were an important part of the debate when the new cash-for-care reform was established in Norway in 1998. The main goal of this reform was to provide parents with the opportunity to spend more time with their children by giving them

NJSR - Nordic Journal of Social Research

Vol. 4, 2013 
money so they could afford to work less and to spend more time at home. Another claim was that the scheme would guarantee parents the freedom of choice' between using publicly funded day care or staying at home and receiving cash for care. The third intention behind the scheme was to create more equality in the use of public support between families with small children not using publicly funded day care and those that did (St.prp. 53, 1997-98:8). The cash-for-care scheme differed from previous parental-leave schemes within Norwegian welfare and family policies because it did not depend on parental participation in the labour force. One of the main goals of Norwegian welfare policies has been to give women and men the possibility to combine the care of small children with an active working life. Improvements and developments of parental leave have been connected to labour-force participation. However, the cash-for-care scheme is not, and it is therefore a separate agreement between the parents and the state.

The reform was introduced 15 years ago and thus we now have substantial background experience of how it has worked. In this article we shall take as our point of departure the period from the introduction of cash for care in 1998 through to the present day. Our focus is on two research themes:

1) What have been the changes over the 15 years in the extent that Norwegian parents have used this care policy?

2) What are the characteristics of the typical users over time?

To do this we have divided the timeline of the new scheme into three periods. Our analyses are based on different sources of statistical data from the Norwegian Labour and Welfare Administration (NAV, Ny Arbeids- og Velferdsforvaltning) and from Statistics Norway (SSB). In addition we use data from the major evaluative study which was carried out by the Norwegian Research Council.

NJSR - Nordic Journal of Social Research

Vol. 4, 2013 


\section{The Dualism in Norwegian family policies - social democratic and Christian democratic approaches}

The dualist aspect in Norwegian family policy (Ellingsæter \& Leira, 2006) has encouraged what have been labelled the 'work-line' policies, meaning that social-insurance programmes are based on parents' work participation. Accordingly, family policies are closely connected to employment policies and encourage parents to choose employment. A typical example of this principle is the qualifying criteria for being eligible to the parental-leave scheme: participation in the workforce for minimum six of the last ten months prior to the birth of the child. This type of policy encourages both parents to combine work and family obligations, which again leads to a dual-earner model where the ideal is that both mothers and fathers should be employed. This is part of what Ellingsæter and Leira (2006) have called the politicization of parenthood', meaning that different governments in the Norwegian political system have contributed to redesigning gender relationships in parenting in the Nordic countries. Approaching welfare policy, we may also understand 'the politicization of parenthood' in connection with what Gøsta Esping-Andersen (2006) has called the 'social democratic' regime. This welfare regime takes direct responsibility for the care of children, but this policy does not only aim to service family needs; it also allows women to choose work rather than the household. Esping-Andersen (2006) points out the merging of welfare and work in the social democratic regime. This welfare strategy is committed to a heavy social-service burden and is dependent on full employment (and thus taxation) in the population (Esping-Andersen, 2006: 169).

The other track in Norwegian family policies, the Christian Democratic and liberal track, has advocated policies that are not dependent on the parents' participation in working life. The family is instead given cash payments in order to value unpaid work and care. The cash-for-care scheme promotes this idea by providing cash benefits irrespective of the parents' earlier workforce activities. This track has come to support a traditional division of work in the family 'the malebreadwinner family model'. Giving more freedom of choice has been a crucial argument for the cash measures in general, and this case refers to cash given particularly to facilitate one of the parents staying at home. Taking into consideration the modest amount of money the cash-for-care scheme gives a family, we may regard it as an option

NJSR - Nordic Journal of Social Research

Vol. 4, 2013 
mainly for mothers with no or very low income. The fact that it is not connected to the obligation to participate in the labour market makes a clear break with the principles of the social democratic welfare-state regime.

Drawing upon Esping-Andersen's notion of welfare-state regimes (Esping-Andersen, 2006), we shall argue that the Norwegian cash-forcare scheme is closer to a 'liberal' or a 'corporatist' welfare-state strategy than a 'social democratic' one. Esping-Andersen claims that family policy in a liberal welfare regime is based on the belief in freedom of choice for individuals and the concerns of gender matter less than the sanctity of the market. The Norwegian cash-for-care scheme was introduced as a gender-neutral arrangement on the basis of ideas from a liberal ideology and a strong belief in the blessing of the freedom of choice. At the same time, the cash-for-care arrangement could be a part of what Esping-Andersen (2006) labels as a corporatist welfare strategy 'typically shaped by the Church and strongly committed to the preservation of traditional family practices' (Esping-Andersen, 2006 p.168). Cash for care has been an important part of the family policy of the Christian Democratic Party in Norway, and their goal is to support traditional family values. The Christian Democratic Party also played a central role in the introduction of the arrangement in 1998. According to Esping-Andersen the most salient characteristic of the social democratic regime is its fusion of welfare and work participation. Cash for care represents a welfare arrangement disconnected from working life. It can be seen as an arrangement that supports a private solution to childcare. In this way cash for care fits in with a liberal as well as a corporatist welfare strategy. Since gender equality matters less in this welfare arrangement it also supports a preservation of traditional family patterns, typical for a corporatist strategy.

We also find expressions of this dualism in the political attitude regarding publicly funded day-care services. Norway has had the lowest coverage rate for these services among the Scandinavian countries, especially for children under three years of age. The main reason for these differences between Norway, on the one hand, and Sweden and Denmark, on the other, has been the political ambivalence towards mothers' participation in the workforce and daycare services for children (Ellingsæter, 2006). The Christian Democratic Party and the Conservative Party have supported a more

NJSR - Nordic Journal of Social Research

Vol. 4, 2013 
traditional family pattern, with mothers staying at home caring for the children. The Social Democratic party and the Socialist Party have supported day-care services for children and mothers' participation in the workforce. This ambivalence has made it difficult to gain sufficient political support for securing full kindergarten coverage in Norway. It was not until 2003 that all political parties joined to sign the so-called the 'day-care guarantee', which stipulated that all Norwegian children between one and six years of age would be guaranteed a place in a publicly funded day-care centre.

Thus, the two tracks have influenced the work-family balance in contradictory ways. The question of which family models the welfare state should support reflects different ideas on what a family is or should be in Norway today. Some family policies aim at conserving a more traditional, male-breadwinner model, whereas others encourage a 'double-earner/double-carer' model. It is important to take into consideration the potential tension between these two models in the context of Norway as a multicultural society.

\section{Family policy and the intersection of gender, class, and ethnicity}

Population data from Statistics Norway show that there has been a considerable increase of immigrants in the Norwegian population over the last 30 years. Beginning in 1970, immigrants and Norwegian born with immigrant parents constituted 1.5 per cent of the population. In 2010 this group had increased to 13.1 per cent of the population ${ }^{1}$ (Statistics Norway, 2012 [http://www.ssb.no/innvandring/]). This change represents new challenges for research and policies introduced in the work-family field. The politicization of parenthood (Ellingsæter \& Leira, 2006) in the Norwegian context has been

\footnotetext{
${ }^{1}$ In recent years there has been an explosive growth in immigration to Norway from new EU countries (Eastern Europe and especially Poland) after the EU enlargement. The number of immigrants from Asia, Africa, and Latin America has doubled since 2000 . The proportion coming from these countries has increased from six per cent in 1970 and now constitutes half of all immigrants. (Statistics Norway, 2010).
}

NJSR - Nordic Journal of Social Research

Vol. 4, 2013 
strongly influenced by universalism and egalitarianism. ${ }^{2}$ These are what welfare analysts generally consider to be the core values in the constitution of the so-called 'social democratic Nordic model' (EspingAndersen, 2006). As the Nordic countries have become societies which to a greater extent include people from different ethnic and cultural backgrounds, this type of welfare-state intervention might represent a new challenge both for social-science theory and for policy-makers.

In their book on intersectionality, De los Reyes and Mulinari (2004) criticize what they see as predominant feminist policies for white middle-class well educated women in the Nordic countries. They find this feminism to be a type of equality policy that can be measured, assessed, and acted upon. One of the consequences of this approach is that the subsequent focus on women's representation in decisionmaking bodies in politics and business and industry obscures issues relating to inequalities between women. Therefore, they argue that it is important to keep women's different life conditions in mind. Thus, instead of a sole focus on gender, the perspective should be on how gender, class, and ethnicity interact. Accordingly, an intersectional perspective focuses on relating white women to hegemonic femininity and shows how ignoring other women's life conditions is an important tool in the reproduction of the hegemonic position of white feminism.

The Nordic countries have maintained a strong focus on affirmative action in order to achieve gender equality, which easily becomes a general narrative of progress that obscures the circumstances of less privileged groups of women in Scandinavia and other countries. The focus should instead be on variations between women's life situations when discussing and suggesting general political measurers. The life situation of women and men is not a sum of disparate segments of race, gender, and class. Rather, all these elements are produced and reproduced each day in historically and locally varying contexts. Societal patterns of segregation, inequality, exploitation, and oppression are concrete historical processes that are constructed as an integral part of class and gender differences. Reducing social

${ }^{2}$ Universalism refers to a welfare policy that is based on egalitarianism in the sense that a universalistic system promotes equality of status (in addition to a means-tested system). All citizens are endowed with similar rights, irrespective of class or market position (Esping-Andersen, 2006).

NJSR - Nordic Journal of Social Research

Vol. 4, 2013 
positions to simple categories (gender, class, or ethnicity) blinds us to the interplay between different forms of superiority and subordination in societal life (De los Reyes \& Mulinari, 2004).

It has nevertheless been difficult for researchers to reach some agreement on how they should understand these types of complex interconnections. This conundrum is expressed in Doing Gender, Doing Difference: Inequality, Power, and Institutional Change (Fenstermaker \& West, 2002). In their book, Fenstermaker and West state that race, class, and gender are experienced simultaneously, and in order to understand this point, it is important to focus on the actual mechanisms that produce inequality. In this regard, they develop an ethno-methodological perspective through which they see interconnections as 'situated accomplishments in interactions in which race, class and gender are enacted and reproduced'.

De los Reyes and Mulinari (2004) have a similar understanding as Fenstermaker and West (2002), where they look for theories to explain processes that create inequality on different societal levels. Central to this endeavour is the approach of 'doing gender', an understanding of gender as a practice which is being constructed in everyday activities (West \& Zimmerman 1987; Kvande, 2007). They maintain that power and power relations are things that are done in the interaction between people. It is also impossible to do gender without at the same time doing class, race, and sexual orientations. Structural relations come into the picture through their contextualization in space and time with the focus on financial relations, dominant ideologies, and social structure. In addition to analysing the intersection or interaction between gender, class, and race, the idea is to interconnect analyses on different levels. This includes policy levels, which are the focus of this article.

Even if it is agreed that race, class and gender should be understood and analysed as interlocking elements, the question of how best to understand the intersections between them has been a key issue (Collins 1995; Glenn 1999, 2002; West \& Fenstermaker, 1995a, Fenstermaker \& West, 2002). Most scholars are critical of simple additive models of gender, race, and class because such models assume common experiences in each of the categories. An additive model does not capture the fact that gender relations vary within different races and class situations. The dilemma is found in the

NJSR - Nordic Journal of Social Research

Vol. 4, 2013 
intersectionality between social structures as opposed to mutually constituting processes. We continue to face the challenge of how to understand what the metaphors of 'mutually constituting', 'intertwining', and 'intersecting' mean in terms of concrete analyses of social practices (Acker 2005).

McCall (2005) has created a three-part typology for understanding and applying the concept of intersectionality. The first is the anticategorical use of the concept, where the focus is on the deconstruction of social categories to introduce more fluid and open understandings of complex processes. The second is the intracategorical approach that focuses on differences that cut across one particular category of interest and is based on in-depth qualitative analyses on, for example, a special group of immigrant women. With the third type, the inter-categorical approach, the main focus is on differences and similarities within groups and it is based on the use of analytically defined categorical differences such as age, social class, ethnicity, and gender. This approach is more used in large-scale quantitative analyses. If the inter-categorical approach is used, the focus will be more on differences than on similarities between groups. Bearing this in mind, in this article we shall use the inter-categorical approach to study how the intersections of gender, class, and ethnicity produce different practices in the use of cash-for-care policies.

\section{Data and methodology}

In our analyses of the development in the use of the cash-for-care scheme, we decided to divide the timeline of the new scheme into three strategic periods. We have called this the 'rise and fall of the cash for care', indicating the change in the support for this reform.

The first period starts in 1998, when cash for care was introduced, and ends in 2005. In 2003, all the political parties joined together and signed 'the childcare guarantee', which meant that all children between one and six years of age would be guaranteed a place in public day care. The second period lasts from 2005 to 2009, and the last period is from 2009 up to today.

Our analysis is based on different data sources. For describing the use of the cash-for-care arrangement and analysing it through the three periods, we use two main sources of statistical data. This is data

NJSR - Nordic Journal of Social Research

Vol. 4, 2013 
available from the Norwegian Labour and Welfare Administration (NAV http://www.nav.no/English) and from Statistics Norway (SSB http://www.ssb.no/english/).

NAV carried out a survey on the use of cash for care between April and May in 2010 a representative sample of parents in Norway (Bakken \& Myklebø, 2010). Data used for this analysis was obtained from Government Statistics register data; the cash-for-care register, (Kontantstøtteregisteret), the employer and employee register (Arbeidsgiver-/arbeidstaker registeret), the income register (Inntektsregisteret) and more. The data contains all children born from 1998 to 2007 and information about their parents (Bakken \& Myklebø, 2010).

We also used similar statistical studies from Statistics Norway to describe patterns of use for the cash for care through the period of 1999 to 2010 (Gulbrandsen \& Hellevik, 1998; Hellevik, 2000, Pettersen 2003, Rønsen 2004 \& Hirch 2010) and in addition the latest statistical data on immigration and immigrants to Norway (Statistics Norway, 2012).

NJSR - Nordic Journal of Social Research

Vol. 4, 2013 


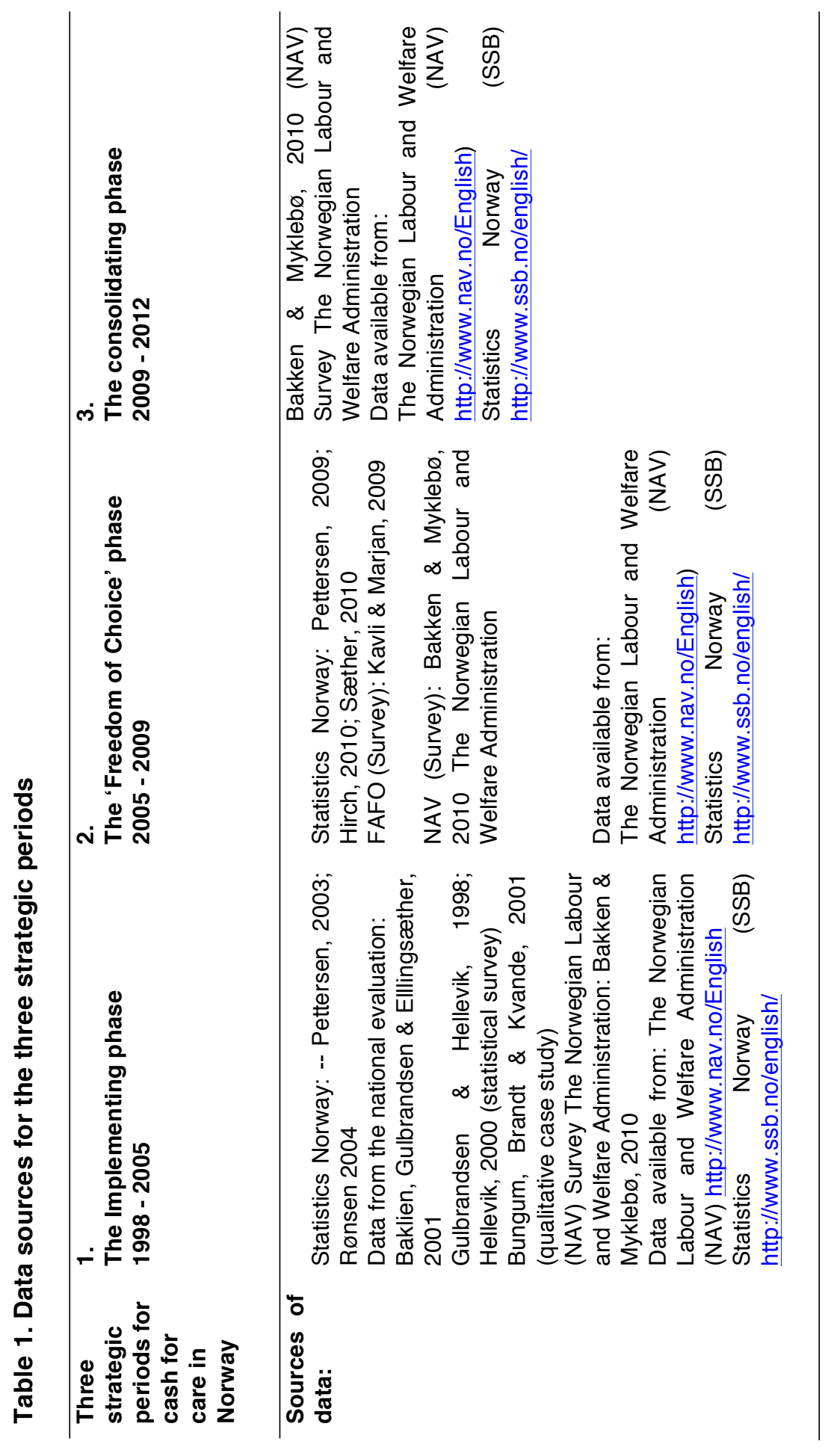

NJSR - Nordic Journal of Social Research

Vol. 4, 2013 
Four years after the introduction of the cash-for-care scheme the Norwegian Research Council conducted a major evaluation that included several studies. Two surveys were conducted before and after the reform (Gulbrandsen \& Hellevik 1998; Hellevik, 2000) along with two qualitative case studies. In one of the qualitative case studies (Bungum, Brandt \& Kvande, 2001), the main focus was on examining the consequences for equality between women and men in working and family life. In many ways this research question reflected the public debate on the dual-earner model, and this study has found that different work cultures were important when it comes to the possibilities parents have for spending time and providing care for their own children, and also for what sort of care arrangements they choose to use. The data, which illustrates different contexts of Norwegian working life today, was based on case studies from three different workplaces with various time-cultures, that is, the norms directed towards working time (Epstein et al., 1999; Brandth \& Kvande, 2005). This study focused on fathers and mothers working as skilled workers in the electronics industry, nurses in a hospital, and researchers working in technological research (Bungum et al., 2001). One of the members of this research group analysed the family policy debates in parliament prior to the introduction of the reform (Håland, 2001). These are the main data sources in our analysis of the first period, which we have labelled it 'the implementing phase'.

In 2002 a new study was conducted on the effects on families with respect to their use of childcare, work participation, and use of cash for care (Pettersen, 2003). This material has been used in a number of analyses (Rønsen, 2004). We use these results as our point of departure in our analysis of the second phase, 'the decline-of-usage phase'. In the last phase, which we have labelled the consolidation phase, we use the latest analyses from Statistics Norway which focus on the decline in the use of cash for care among different parental groups (Hirch, 2010) together with the survey from The Norwegian Labour Welfare Administration (Bakken \& Myklebø, 2010).

\section{The implementing phase - a dramatic rise in usage}

The cash-for-care scheme was introduced in 1998, and it was greatly used in this initial period. It was at the peak of its popularity and measured in terms how many families received the cash benefit.

NJSR - Nordic Journal of Social Research

Vol. 4, 2013 
Statistics show that parents of 91 per cent of the children born in 1998 and 1999 received cash for care, and if we look at children born in 2000 and 2001, the numbers are almost identical (Bakken \& Myklebø, SSB, NAV, 2010). When the numbers are as high as this, it indicates that families in all social groups received the scheme. However, when we analyse more closely how the cash-for-care scheme was actually used, we find that it was used in quite different ways by different groups of parents.

Although the main purpose of the scheme was to give parents the opportunity to spend more time with their children, we find that a large number of parents who received cash for care during this period used a private nanny or made other private arrangements, for example using grandparents or other relatives. During this period in Norway, few day-care centres had places for one- and two-year-olds. While the intention of the planners of the cash-for-care scheme was to give parents the opportunity to spend less time in the workplace and more time with their children, the opponents of the scheme feared that that a large number of working mothers would leave the workforce. However, the evaluation's summary report (Baklien, Gulbrandsen \& Ellingsæter, 2001) concluded that this major reform had minimal impact on the mother's practices of workforce participation.

The debate about the 'time bind' was important in the first phase when the new cash-for-care reform was established in Norway in 1998. At this time a growing number of mothers were working on a full-time basis in Norway and, therefore, correspondingly more and more children were born into dual-earner families. The concept of the time squeeze' or 'time bind' was often used in the public debate to describe the situation for many of these families. A popular idea in Norway was that flexibility was a key solution to the time-bind problem for working parents, not only at the workplace but also in family policy in general. The strong belief in flexibility as a blessing for parents had clear connections to the (liberal) arguments based on parents' rights to have the freedom of choice in caring for their children (Brandth, Bungum \& Kvande, 2005).

Although cash for care at first glance appears to be a gender-neutral scheme, open to both fathers and mothers, research findings have shown that virtually no fathers reduced their work time owing to the scheme. The main cash for care was for part-time working mothers

NJSR - Nordic Journal of Social Research

Vol. 4, 2013 
(Hellevik, 2000). Part-time work is not common among Norwegian fathers. Moreover, time cultures in working life seem to influence the way cash for care is used.

While Norwegian family policies have been presented as attempts to reduce inequality between women and men, cash-for-care policies were not introduced as a scheme for supporting gender equality. The former minister of children and family affairs, Valgjerd Svarstad Haugland, (who is said to be 'the mother of the cash-for-care scheme' in Norway), had the following comment when asked if it was problematic that the scheme would maintain a traditional genderbased division of labour:

I never said that the cash-for-care scheme was going to be a reform promoting equality among men and women, and this I maintain. It is a scheme for parents who wish to spend more time with their children.

While one might consider arguing that cash for care is a genderneutral scheme, the statistics indicate that the majority of those who used cash for care to reduce their working hours were women with weak labour-market connections. Thus, we see an intersection of gender and class, although some middle-class women also worked on a part-time basis. Fathers, on the other hand, did not use the scheme to work less (Hellevik, 2000). The cash-for-care scheme, therefore, clearly had some gendered consequences (Bungum, Brandth \& Kvande, 2001).

Our research findings from this introductory phase revealed that gender was important in the choices parents made. Norwegian working life is gendered in ways that include different time cultures in different workplaces. We included two male-dominated companies in our study. In both of these companies we found that the labour rights were the crucial concern when it came to the fathers' possibilities to use more time for the care of their children. Our research showed that if fathers are going to work less and are taking on more care duties at home, the welfare schemes have to be connected to labour rights. Although cash for care was said to be a gender-neutral scheme with the same impact for mothers and fathers, gendered time cultures in the workplace were adjusted to a gendered use of the scheme. Parents' choices in connection with cash for care appeared to be

NJSR - Nordic Journal of Social Research

Vol. 4, 2013 
individual and particular, but together they made a pattern that strengthened the impression that cash for care was a scheme that maintained and reinforced a traditional pattern of gender division.

\section{The decline-in-usage phase}

This phase in a way commences in 2003 with the introduction of the day-care guarantee' and lasts up to 2009. In the political debate prior to the introduction of the cash-for-care scheme, the Christian Democratic Party and the conservative parties argued that it would guarantee parents 'the freedom of choice' between using publicly funded day care or staying at home and receiving cash for care. The Norwegian Labour Party and other parties on the left saw this scheme as a break with the dominant dual-earner and dual-carer model and argued that as long as there were not enough publicly funded daycare places, there would be no real freedom of choice.

In other words, this political disagreement mirrors the dualism in the Norwegian policies in this area. Because of the ambivalence towards mothers active in the labour market and publicly funded day-care services, Norway has had the lowest coverage rate for these services among the Scandinavian countries, especially for children under three years of age. Because of this ambivalence, it has been difficult to gain full support for the political aim of securing full kindergarten coverage in Norway. In the political debate that followed the introduction of cash for care, politicians from both left- and right-wing parties pointed out that it was impossible to say that Norwegian parents had freedom of choice between these two alternatives as long as day-care services were not fully covered. The important result of this debate was that all the political parties joined together in 2003 and signed what was called the 'day-care guarantee', which meant that all Norwegian children between one and six years of age would be guaranteed a place in publicly funded day care. Thus we can say that it was after 2003 that Norwegian parents really had the freedom of choice that they were promised in the 1998 election. However, it took some time before the effect of this reform could be studied because new daycare facilities had to be built. Therefore, the second phase in our analysis really starts in 2005 when we can see a dramatic drop in the number of those opting for cash for care.

NJSR - Nordic Journal of Social Research

Vol. 4, 2013 
The figures from Statistics Norway indicate this development (Hirch, 2010). In 2009, 32400 children between one and two years were under the cash-for-care scheme. In 1999, ten years earlier and one year after the introduction of the scheme, the number was 88700 and the relative figures for all one to two year olds went from 73 per cent in 1999 to 27 per cent in 2009. More one year olds receive cash for care than two year olds. For one year olds, we see a drop from 78 per cent in 1999 to 30 per cent in 2009. For two year olds, we see a drop from 69 per cent to 24 per cent in the same period. There has been a gradual reduction in the use of cash for care during the entire period from 1999 to 2009, but the reduction has been most prominent after 2009.It is therefore reasonable to say that the majority of parents during this second phase have chosen not to use cash for care. When Norwegian parents really obtained the freedom of choice, they preferred day-care services to cash for care.

However, it is important to look at who used cash for care in 2009. For Norwegian parents, we can see the same pattern as in the first phase; mothers with a marginal position in the labour market used the cashfor-care scheme. This trend is even stronger in the second phase. We can see the same pattern for immigrant families. There has been a decrease in the use of cash for care among all groups of immigrants (Hirch, 2010). The figures show, however, that children between one and five years of age with parents from Africa and Asia do not use publicly funded day-care services to the same degree as children with parents from Norway (Sæther, 2010). The use of the cash-for-care scheme varies according to what country the immigrants come from. Parents from Pakistan have the highest percentage of cash-for-care usage, which is true for the whole period, from 1999 to 2009.

The variation between the different immigrant groups when it comes to using the cash-for-care scheme must be seen in connection with women's participation in the workforce. Women from Pakistan, Iraq, and Somalia have low participation rates in working life and the gender difference between men and women in labour-market participation within the various groups is greatest among those from Pakistan (Pettersen, 2009). Research within this field finds that immigrants from Pakistan often are of the opinion (60 per cent) that women should not be in the workforce if they have children between one and three years of age (Kavli \& Marjan 2009). This opinion is held by only one-third of immigrants from Iran, one-fourth from Iraq, and

NJSR - Nordic Journal of Social Research

Vol. 4, 2013 
under one-fifth from Vietnam. In comparison, only 11 per cent of parents without an immigrant background have this opinion (Kavli \& Marjan, 2009).

\section{The consolidating phase - the decline in usage continues}

The third phase starts in 2009 and continues up to today. The trend of a decreasing popularity among parents in using the cash-for-care scheme continues in this phase. Patterns revealing differences in economic, social, and cultural background among parents' preferences towards childcare are becoming even more prevalent (Bakken \& Myklebø, 2010). The majority of parents in Norway seem to prefer day care for their children. While the recipients of cash for care in the first phase constituted a heterogeneous group of parents, the recipients in the third phase are more and more a homogenous group of parents when it comes to class and ethnicity.

The real value of the amount of money parents receive from the cashfor-care scheme has diminished since the introduction of the reform. At the same time, the day-care rates have decreased. Relatively speaking, in the period of the third phase it is more expensive to stay at home with small children in Norway. The relative value of the money from the scheme is, however, higher for parents with low income than for parents with high income. The latest statistical analyses (NAV 2010) show that parents with low income receive cash for care to a larger extent. In regard to opting for cash for care, the income of mothers is the decisive factor. The higher the mother's income is, the weaker her propensity for opting for cash for care. Naturally this is also connected to the mother's educational level and profession. Low workforce participation seems to increase the probability of choosing cash for care (Bakken \& Myklebø. 2010). These findings indicate that mothers' relations to the labour market continue to be an important key to understanding the function of the cash-for-care scheme in Norway today.

Parents with an immigrant background are over-represented, as are those with low income and low education as well as with a rural address among today's cash-for-care receivers. The statistics for the

NJSR - Nordic Journal of Social Research

Vol. 4, 2013 
receivers of cash for care (NAV 2010) also tell us that the differences between immigrant parents and parents born in Norway are increasing, and parents born in Asia and Africa are more likely to receive cash for care than parents born in Norway (Bakken \& Myklebø, 2010).

These differences have come to influence the political discussion on the integration of immigrants in Norway. How can small children learn to speak the Norwegian language if they stay at home? How do we encourage immigrants to participate in the workforce while simultaneously offering welfare schemes that encourage them to stay at home? There have been political proposals to abolish the cash-forcare scheme, but a majority still support it. It would appear that the freedom of choice for parents continues to be a popular idea in the public discourse. Even though popularity in the cash-for-care scheme has obviously declined, it can still be a political risk to remove a scheme that pays poor parents (mothers) cash for care. The discussion also reflects a problematic issue concerning the idea of gender equality between parents in the Norwegian society and immigrants with more traditional ideas about parenthood and gender relations.

\section{Summary and conclusions - the rise and fall of cash for care}

In this article we have analysed the development in the use of the cash-for-care scheme in Norway. We have shown how the use of cash for care has changed during the 14-year period it has existed. This development we have called 'the rise and fall of the cash-for-care scheme'. We have applied two theoretical points of departure. First, we have applied the theories on different welfare-state regimes in order to analyse the 'politicization of parenthood' in the Norwegian context. The Norwegian welfare state has followed a double track in family policies, introducing regulations which support the dual-earner model but also introducing regulations supporting the malebreadwinner model. The cash-for-care system which is not based on parent's workforce participation can be said to support the malebreadwinner model. It is also a break with the social democratic welfare regime which relies on the merging of welfare and

NJSR - Nordic Journal of Social Research

Vol. 4, 2013 
participation in the workforce. Our second strand of theorizing is based on the perspectives of intersectionality. We have applied the inter-categorical approach where the main focus is on differences and similarities within groups and it is based on the use of analytically defined categorical differences such as age, social class, ethnicity, and gender.

By distinguishing between three separate phases our intention has been to illustrate the different ways the intersection of gender, class, and ethnicity has entered into both the discourse and the practices connected to the cash-for-care scheme since it was introduced in 1998. In the beginning, as illustrated by the first phase in our analysis, cash for care was used by a fairly heterogeneous group of parents, whereas usage today is concentrated in a fairly homogeneous group where gender intersects with class in such a way that mothers with low income and low education are encouraged to stay outside the labour market.

In the first phase the main issue in the political discussion was about gender and the question of equality in the family. One of the topics in the heated debate on these policy measures was whether the cashfor-care scheme would undermine the dual-earner model by encouraging mothers to 'return to the kitchen' and leave paid work. The first evaluative analyses that were carried out in 2001 has shown that cash for care had been 'a big reform with small consequences' (Baklien, Gulbrandsen \& Ellingsæter, 2001), which meant that the number of mothers in the workforce did not decrease significantly. However, this research was undertaken a short time after the introduction of the reform. Later research on this topic indicated that the effects on mothers' participation in the workforce were not so small after all (Rønsen, 2004). This research also showed that there were substantial differences between different groups of women according to their educational background. This concurs with other research that shows how class and educational backgrounds have a significant effect on the care strategies parents choose (Stefansen \& Farstad, 2008)

The second phase started in 2005 after the introduction of 'the daycare guarantee' in 2003. This was followed by a dramatic fall in use of cash for care. In this phase, the focus in the public debate on cash for care slowly turned from gender towards class and ethnicity. When

NJSR - Nordic Journal of Social Research

Vol. 4, 2013 
parents in Norway received real 'freedom of choice', the majority preferred publicly funded day care for their children. Immigrant mothers with a marginal position in the labour market were the majority of the users of the cash-for-care scheme. This is an example of how ethnicity, class and gender intersect. At the same time there has also been a decrease in the use of cash for care among all groups of immigrants. However, the statistics tell us that parents from some countries in Africa and Asia do not use day-care services to the same degree as parents with a Norwegian background. We have pointed out how variations between the different immigrant groups regarding the use of the cash-for-care scheme must be seen in connection with how women's participation in the workforce is viewed.

In the last phase, this tendency becomes even more evident. We find that parents with an immigrant background and parents with low incomes and education are the ones who use the cash-for-care scheme. The most important background factors are the education and income situation of the mothers. The intersection of gender, ethnicity, and class becomes very clear, for it is mothers with low education and income and from immigrant families who are among the main users of cash for care. In this third phase questions concerning ethnicity and the integration of immigrants in the labour market are also highlighted in the public discussion.

Recently the Norwegian government has proposed redesigning the cash-for-care scheme for three-year-olds. It will then be limited to parents with children up to two years of age. The argument for this reduction is that it will be an adjustment that will lead to more women participating in the workforce. It is further argued that more immigrant children would have the opportunity to learn the Norwegian language in day-care centres, which will in turn benefit their opportunities in school. The political debate on this issue remains controversial.

Cash for care has developed into a scheme which is used by mothers in the lowest income groups and with a high percentage of certain groups of immigrants. Because of this pattern, it is also a difficult political decision to redesign it, even though it is quite dysfunctional when it comes to the political aims of increasing gender equality and the integration of ethnic minorities.

NJSR - Nordic Journal of Social Research

Vol. 4, 2013 


\section{References}

Acker, J. (2005) Class Questions: Feminist Answers. Lanham, MD: Rowman and Littlefield.

Bakken, F. \& Myklebø, S. (2010). Kontantstøttens utbredelse og foreldres preferanser for barnetilsyn [The extent of the cash-for-care scheme and parents' preferences for childcare]. Arbeids- og velferdsdirektoratet.

Baklien, B., Ellingsæter, A.L. \& Gulbrandsen, L. (2001). Evaluering av kontantstøttereformen [Evaluation of the cash-for-care reform] Oslo: The Norwegian Research Council.

Brandth, B., \& Kvande, E. (2003). Fleksible fedre [Flexible Fathers] Oslo: Universitetsforlaget.

Brandth, B. \& Kvande, E. (2005). Fedres valgfrihet og arbeidslivets tidskulturer [Fathers' freedom of choice and time cultures in working life] Oslo Tidsskrift for samfunnsforskning, 46(1), pp. 35-54

Bungum, B., Brandth, B. \& Kvande, E. (2001). Ulik praksis - ulike konsekvenser. En evaluering av kontantstøttens konsekvenser for likestilling $i$ arbeidsliv og familieliv [Different practices, different consequences: An evaluation of the consequences of cash benefits for gender equality in working life and family life] Rapport STF 38 A01502. Trondheim: SINTEF-IFIM and NTNU.

Børve, H. E. \& Kvande, E. (2006). Kjønnede tidskulturer i en global Kunnskapsorganisasjon (Gendered Time Cultures in a globalized Knowledge Organization) Tidsskrift for kjønnsforskning, 3-4: 352-368.

Collins, P. H. (1995). Symposium: On West and Fenstermaker's 'Doing Difference'. Gender and Society, 9(4), pp. 491-494.

de los Reyes, P. \& Mulina, D. (2004). Intersektionalitet. Malmø: Liber.

Ellingsæter, A. L. (2003a). The Complexity of Family Policy Reform: The Case of Norway. European Societies, 5(4) pp. 419-443

Ellingsæter, A. L. (2003b). Når familiepolitikk ikke virker... Om kontantstøttereformen and mødres Iønnsarbeid [When family policy does not work ... On the cash-for-care reform and mothers' paid work]. Tidsskrift for samfunnsforskning, 44(4), pp. 499-527

NJSR - Nordic Journal of Social Research

Vol. 4, 2013 
Ellingsæter, A. L. (2006). The Norwegian childcare regime and its paradoxes. In Ellingsæter, A. L. \& Leira A. (eds.) (2006) Politicising Parenthood in Scandinavia. Bristol: The Policy Press.

Ellingsæter, A. L. \& Leira. A. (eds.) (2006). Politicising Parenthood in Scandinavia. Bristol: The Policy Press.

Epstein, C. F., Seron, C., Oglensky, B., \& Sauté, R. (1999). The Part-time Paradox: Time Norms, Professional Life, Family and Gender. London: Routledge.

Esping-Andersen, G. (2006). Three Worlds of Welfare Capitalism. In Pierson, P. \& Castles, F. (eds.), The Welfare State Reader (pp. 160-174). Cambridge: Polity Press.

Fenstermaker, S. \& West, C. (eds.) (2002). Doing Gender Doing Difference: Inequality, Power, and Institutional Change. London: Routledge.

Glenn, E. N. (1999). The Social Construction and Institutionalization of Gender and Race: An Integrative Framework. In Lorber, J., M. M. Feree \& B. Hess, Revisioning Gender (pp. 3-43). Thousand Oaks, California: Sage.

Glenn, E. N. (2002). Unequal Freedom: How Race and Gender Shaped American Citizenship and Labor. Cambridge, MA: Harvard University Press.

Gulbrandsen, L. \& Hellevik, H. (1998). Barnehager og kontantstøtte i et fordelingsperspektiv [Day-care centres and cash for care in a distributive perspective] Samfunnspeilet $n r .5,1998$. Oslo. SSB

Hellevik, T. (2000). Flere småbarnsmødre har blitt deltidsarbeidere [More mothers have become part-time workers] Samfunnspeilet nr. 5, 2000. Oslo. SSB

Hirch, A. A. (2010). Brukere av kontantstøtte 1999-2009 Færre barn med kontantstøtte [Users of cash for care 1999-2009: Fewer children with cash for care] Samfunnsspeilet nr.4, SSB 2010

Håland, K. (2001). Kontantstøtten: et veiskille i norsk familiepolitikk? [Case for care: a crossroad in Norwegian family policy?) Hovedfagsoppgave i statsvitenskap. Trondheim: Institutt for sosiologi og statsvitenskap, NTNU.

Kavli, H. C. \& Marjan, N. (2009). Familiepraksis og likestilling i innvandrede familier [Family practice and gender equality in immigrant families] FAFO rapport 2009:39.

NJSR - Nordic Journal of Social Research

Vol. 4, 2013 
Kvande, E. (2007). Doing Gender in Flexible Organizations. Bergen: Fagbokforlaget

Kvande, E. \& Rasmussen, B. (eds.) (2007). Arbeidslivets klemmer. Paradokser $i$ det nye arbeidslivet [The Working Life Squeeze: Paradoxes in The New Working Life]. Bergen: Fagbokforlaget

Leira, A. (1998). Caring as Social Right: Cash for Child Care and Daddy Leave. Social Politics, 5(3) pp. 362-378

Leira, A. (2002). Working Parents and the Welfare State: Family Change and Policy Reform in Scandinavia. Cambridge: Cambridge University Press

McCall, L. (2005). The complexity of intersectionality. Signs: Journal of Women in Culture and Society, 30(3), pp. 1771-1800

Pettersen, S. V. (2003). Barnefamiliers tilsynsordninger, yrkesdeltakelse og bruk av kontantstøtte våren 2000 [Families with children and care schemes, work participation and use of cash for care spring 2000] Rapporter 2003/9 Oslo. SSB.

Rønsen, M. (2004). Kontantstøtten og mødres arbeidstilbud. Større virkninger på lengre sikt [Cash for care and mothers' work participation in the long term] Samfunnspeilet nr. 6, 2004 SSB

Sigle-Rushton, W. (2007). Looking for Difference? Complexity. Interdisciplinary Communications. 2006/2007, pp. 93-96

Sletvold, L. (2000). Kontantstøtteordningens konsekvenser for yrkesaktivitet og likestilling [The consequences of cash for care for employment and gender equality]. Report 15/00. Oslo: NOVA

Sletvold, L. (2000). Kontantstøtteordningens konsekvenser for yrkesaktivitet og likestilling [The consequences of cash for care for employment and equality]. Report 15/00. Oslo: NOVA

Stefansen, K. \& Farstad, G.R.(2008).Småbarnsforeldres omsorgsprosjekter. Betydningen av klasse [Care arrangements among parents with small children and the significance of class] In Tidsskrift for samfunnsforskning, 3(49), 2008

St. prp 53. (1997-98).Kontantstøtte som ledd i en god barne- og familiepolitikk [Cash for care as a element in positive children and family policy] Kap.2, 2.1 Regjeringens utgangspunkt og mål [Proposal to the Norwegian Parliament: The Government's point of departure and aims]. Report to the Norwegian Parliament no. 4, (1988-89)

NJSR - Nordic Journal of Social Research

Vol. 4, 2013 
Sæther, J. P. (2010). Barn i barnehage - foreldrebakgrunn og utvikling de seneste årene [Children in day care: parental background and development in recent years] Rapporter 2010/11 Oslo SSB

West, C. \& Fernstermaker, S. (1995). Doing Difference, Gender \& Society, $9(1)$, pp. 8-38

West, C. \& Zimmerman, D. (1987). Doing Gender, Gender \& Society. 1(2), pp. 125-151.

NJSR - Nordic Journal of Social Research

Vol. 4, 2013 